\title{
Adobe Soil-Cement Bricks Reinforced with Recycled Kraft Paper Fibers
}

\author{
Elise Oliveira Schweig ${ }^{1}$, Raul Tadeu Lobato Ferreira ${ }^{1}$, Greyce Bernardes de Mello Rezende ${ }^{\mathbf{1}}$, \\ Vinicius Borges de Moura Aquino ${ }^{2}$, André Luis Christoforo ${ }^{2, *}$, Francisco Antonio Rocco Lahr ${ }^{3}$ \\ ${ }^{1}$ Earth and Exacts Sciences Institute (ICET), Federal University of Mato Grosso, Barra do Garças, Mato Grosso, Brazil \\ ${ }^{2}$ Centre for Innovation and Technology in Composites - CITeC, Department of Civil Engineering (DECiv), \\ Federal University of São Carlos, São Carlos, Brazil \\ ${ }^{3}$ Department of Structural Engineering (SET), University of Sao Paulo, São Carlos, Brazil
}

\begin{abstract}
Civil Construction Industry impacts significantly the environment, being one of the most critic factors related to elevated production of Civil Construction Residue (CCR). Among CCR produced, the Kraft paper package acquires notoriety, due their large use on material packaging, such as Portland cement and lime, then, present a high production rate and offer contamination potential, lack of collection logistics and nearly any reuse. In this scenario, the study and development of alternative constructive materials which applies the sustainability concept and CCR recycling have acquired great relevance in the sector. It is highlighted the residue incorporation on masonry soil-cement blocks, due its block are not submitted to the sintering process. Then, the present research intend to study adobe blocks mechanical properties based on soil-cement reinforced with cellulose fibers obtained from Kraft paper recycling. The bricks were confectioned with 7\% Portland cement content and with $0 \%, 8 \%, 10 \%$ e $12 \%$ Kraft paper fiber addition, being submitted to compressive strength test, water absorption test, durability test with wetting and drying and retraction analysis. It was verified the confectioned composites presented as a viable and interesting alternative on technical and environment range. All studied researches presented null retraction and compressive strength increase on cracked state, toughness increase and good performance about durability.
\end{abstract}

Keywords Adobe, Soil-Cement, Civil Construction Residue, Kraft Paper, Sustainability

\section{Introduction}

The Civil Construction Industry (CCI) provokes a great environmental impact on their activities, mainly on intense exploitation of non renewable feedstock, elevated consumption of water and energy, emission of pollutants and generation of great amount of solid waste, which frequently are nor reused or destined appropriately [1-3].

Considering that, sustainability has become extremely important for development of CCI, which started to change the actual model of exploitation and solid residue management based on technology improvement, materials, constructive techniques and production models that employs ecology concepts. Also, fomenting public, institutional policies on economic, environmental and social range on education, environmental conscience on CCI professionals and consumer market [3].

* Corresponding author:

alchristoforo@gmail.com (André Luis Christoforo)

Published online at http://journal.sapub.org/ijme

Copyright @ 2018 The Author(s). Published by Scientific \& Academic Publishing

This work is licensed under the Creative Commons Attribution International

License (CC BY). http://creativecommons.org/licenses/by/4.0/
It is well known that civil construction activities produces residues. This scenario is more concerning on urban regions due to urbanization process and accelerated industrialization, population growth and bad spatial organization of urban center [4].

The disturbs caused by Civil Construction Residues (CCR) are originated, mainly, as a consequence of the great volume of CCR produced, which represents an amount of 50 to $70 \%$ of total urban solid residue generated in Brazil [4, 5].

On actual scenario in Brazil, nearly $72 \%$ of Brazilian municipalities presents collection and management CCR service on operation. Of this parcel, less than $10 \%$ displays processing for CCR screening and recycling, An extremely low rate, considering great amount of residues produced by Brazilian CCI [5]. Then, as the correct as the irregular CCR disposition generates problems and elevated costs for public authorities [5, 6].

On economic level, this costs are related to public cleaning and sanitation, larger areas for landfills, urban regions devaluation, higher risks of ecosystem contamination and proliferation of vectors and diseases $[3,5]$.

The social impacts referent to CCR mismanagement are characterized by degradation of life quality of population and the increase of social inequality, due to the presence of low 
income communities near landfills. Therefore, this parcel of population is exposed in a direct form to problems related to lack of public sanitation [4].

Considering, then, the interdependency between residue generation, environment, public sanitation and population life quality, it is urgent the search for adequate destination of CCR and CCR management in Brazil [6].

In this context, the utilization of materials provided by renewable resources and with recycling potential are practices that offers great contribution for sustainable development of CCI [7]. It happens due recycling allows residue to return for productive chain as a low cost secondary feedstock, reducing the demand of extraction and consumption of non renewable feedstock and minimizing the problems related to elevated RCC production $[3,5]$.

Among CCR, it can be highlighted the Kraft paper, material which, in Brazil, are used as chemical products package, such as the Portland cement [8]. It owns good physical and mechanical properties provided by its production process, which confers higher durability and burst and rent resistance $[9,10]$.

According the Annual Report of Brazilian Cement Industry Union (SNIC) [11], it was verified the Brazilian consumption of cement was nearly 71 millions of tons, with $66 \%$ of this amount packaged with Kraft paper. This information reflects the expressive volume of approximately 937 millions of cement bags discarded.

Despite this fact, the material presents logistic problems and whimsy recycling rate due to the contamination that Kraft paper are submitted by its contact with chemical products, demanding a particular treatment for posterior recycling, not able to receive the same destination of ordinary paper [8]. Most of Kraft paper residue are destined for landfills, burned or inappropriately discarded, which causes pollution and water and soil contamination [8-10].

Alternatives for recycled Kraft paper as secondary feedstock studied by ICC professionals are related to fiber incorporation on cement materials, such as concrete blocks with no structural function [10], composites [12, 13] and mortars [14-16]. It is noted that any study investigated the Kraft paper fiber addiction on adobe bricks.

Also, researches were found whose methodology evolves Kraft paper recycling added on plaster [17], and employed with plastic of disposable cups to produce ecological sidings [18].

Still, it can be checked studies that evaluates Kraft paper use as a geotechnical material for soil stabilization [9] and its addition on Compressed Soil Block (CSB) for vertical seal $[8,9]$.

Another advantageous alternative associated to $\mathrm{CCI}$ sustainable development is represented by soil use as construction material, due the fact it is an abundant, renewable, recyclable, nontoxic and low cost feedstock [20, 21], highlighted the use of constructive techniques related to established soil block, also known as ecological bricks [22].
One of referred techniques is adobe, which represents one of the most ancient and well-known soil construction technique, presenting constructions all over the globe, adapting well to climate and geographical conditions, factors that pushed it to be the architectonic basis of several civilizations [1,22].

Many of this ancient constructions are still on use, representing the quality and durability of adobe as construction material. As an example, the 8,000 years old Catal Hüyük city, in Turkey; Ganj-Dareh, in Iran, built around 7,000 B.C.; Ramses II barns, dated of 4,500 years in Egypt, parts of Great Wall in China and the Djénne mosque, in Mali, dated of 1,280 A.C., considered the largest construction on soilin the world. [22].

Adobe presents as a quick and easy constructive technique, also offers thermal and acoustic isolation, consumes abundant and renewable feedstock, demands low cost equipments, dismiss specialized workforce and enables several forms and dimensions [1,21-23]. Beyond that, it is not performed the sintering process on the block, producing less residues and pollutants and demanding less energy on its manufacturing.

In addition, soil constructions techniques offers great potential for incorporation and association with several types of residues and fibers, either civil construction or from other industries [23].

In this context, it is realized the need for Kraft paper residue as its potential to be incorporated on soil based masonry components. Therefore, intending to collaborate with the increasing searches focused on sustainability and low environment impact, the present study aims to evaluate the technical viability of soil-cement adobes stabilized with cellulosic fibers of recycled Kraft paper provided from Portland cement packages.

For such, they were verified properties as retraction, compressive strength, water absorption and durability by wetting and drying (accelerated aging) on blocks with $0 \%$, $8 \%, 10 \%$ e $12 \%$ Kraft fiber content at 7 -day curing age.

\section{Material and Methods}

\subsection{Materials}

\subsubsection{Soil}

Soil was harvested in Pontal do Araguaia city, Brazilian state of Mato Grosso, from an opening with $2.5 \mathrm{~m}$ depth, on the banks of ring road which connects BR-150 and BR-070 railroads, illustrated on Figure 1. The organic layer was dismissed.

The soil characterization was made from the determination of granulometric composition [25], liquid limit (LL) [26] and plasticity limit (PL) [27], whose standards are defined by the Brazilian Association of Technical Standards (ABNT). The maximum apparent specific dry mass, according the paving company, is 1.968 
$\mathrm{g} / \mathrm{cm}^{3}$. The classification was performed according American Association of State Highway and Transportation Official (AASHTO).

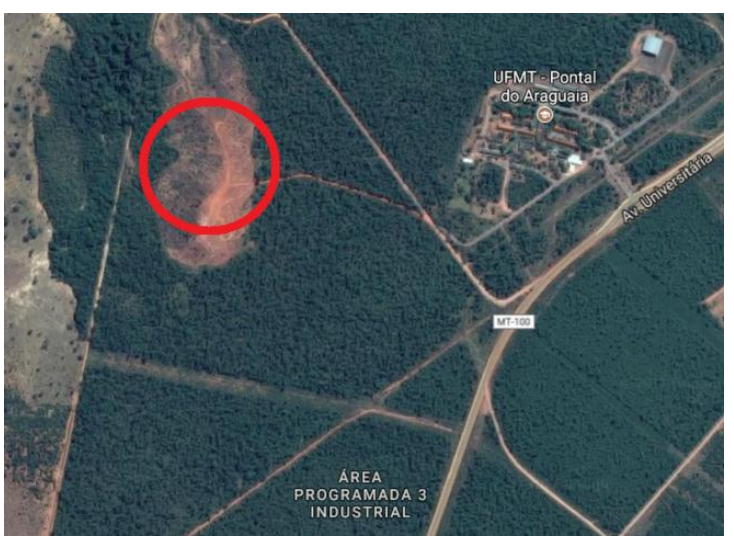

Figure 1. Approximate place of soil harvest (Source: Google Maps [24])

\subsubsection{Portland Cement}

The Portland cement adopted in the present research was the CP-II-Z-32, being the most common in this region. This cement is characterized as composed and its specification is normalized by ABNT [28].

The cement content was determined by tables of Brazilian Association of Portland Cement (ABCP) [29], which provides the average value of binder to be adopted on General Standard of Soil-Cement Dosage. These tables own as entrance data parameters that express the granulometry and soil consistence limits to be stabilized, with different tables for sandy soil and clay soil.

The procedures described on General Standard [29] were not used for dosage effects, the own obtained value on the tables was adopted as the rational and satisfactory cement content.

\subsection{Methods}

\subsubsection{Kraft Paper Fiber Obtaining}

Kraft paper residues were acquired from cement bags gathering on a construction site of a concrete company in Barra do Garças city, Brazilian state of Mato Grosso. Kraft fibers obtaining were performed based on the routine proposed on the literature [8] with some adaptations.

The recycling process consists on the following stages:

a) Bags cleaning to withdraw any residual cement [10];

b) Bag Fragmentation in parts with dimensions inferior to $5 \mathrm{~cm}$;

c) Cellulose pulp obtaining from paper crushing on industrial blender until it acquires pulp consistence (Figure 2).

d) Withdrawal of water excess, leaching the pulp with a cloth;

e) Cellulose pulp dispersion, executed by a rotating metallic stem;

f) Granulometric selection of disperse fiber on a $9.5 \mathrm{~mm}$ opening sieve;

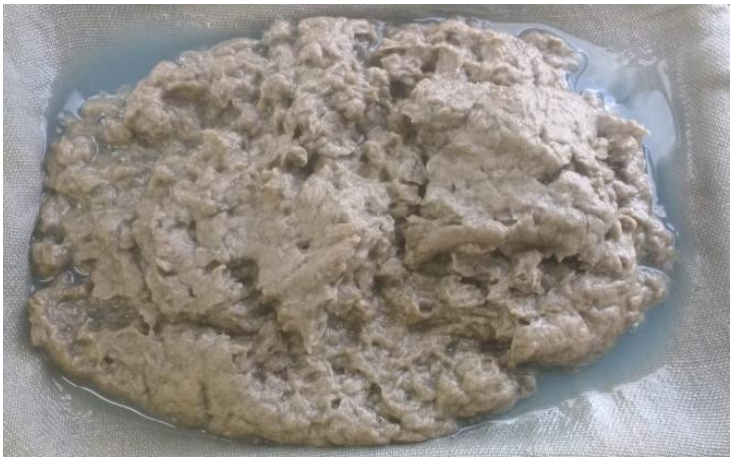

Figure 2. Cellulose pulp after triturating

g) Disperse fibers disposition on tarpaulins to withdraw residual humidity. The final appearance obtained after the selection of Kraft paper fiber is illustrated on Figure 3.

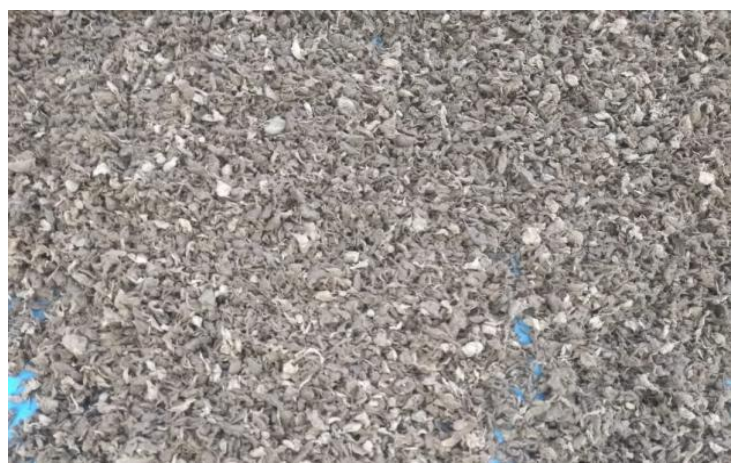

Figure 3. Final aspect of recycled Kraft paper fibers

It is valid to point out the water used on Kraft paper pulping was reused several times, as much as possible aiming to save this natural resource in the recycling process [9].

\subsubsection{Adobe Brick Confection}

The process of mixture preparation was accomplished from the adaptation on the routine proposed in the literature [8] and consisted on the following stages:

(i) Humidifying the concrete mixer walls;

(ii) Disperse Kraft paper fibers with gradual soil incorporation previously mixed with cement, whose objective was avoiding agglomerations, ensuring the mixture homogeneity;

(iii) Addition of little amounts of water until the mass reaches the modeling point, considering the empirical recommendations of adobe technique whose appearance is close to a plaster mortar and presents enough plasticity to fulfill the entire formwork and the block do not deform with its own weight when unformed [22].

The water amount added in the first mixture prepare for each fiber content was replicated on posterior productions of the same proportion, in a manner to ensure the same moisture content for all adobe bricks referent to each trace.

Adobe brick modeling was accomplished on the floor 
covered with canvas and with a cast mold, previously smeared with release agent, capable to produce two brick simultaneously with dimensions $12 \mathrm{~cm}$ width, $24 \mathrm{~cm}$ length and $7 \mathrm{~cm}$ height. The mixture was distributed manually in a manner to fulfill the voids and corners until reach mold height (Figure 4). Blocks were scratched to guarantee face parallelism.

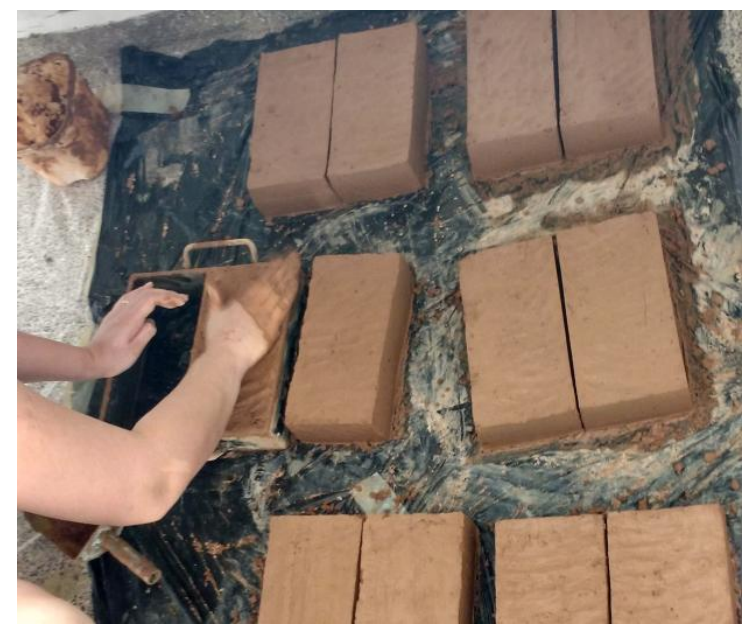

Figure 4. Adobe modeling on steel cast mold

Blocks cure were performed covering the blocks with canvas in the same place of confection due its great plasticity after deforming. After two days every brick was packaged on individual plastic bags to seal it completely, then, bricks were disposed on wood pallets (Figure 5), with no excessive ventilation, simulating the conditions of a humid chamber. Thus, the accelerated humidity loss was prevented and cement hydration reactions were guaranteed.

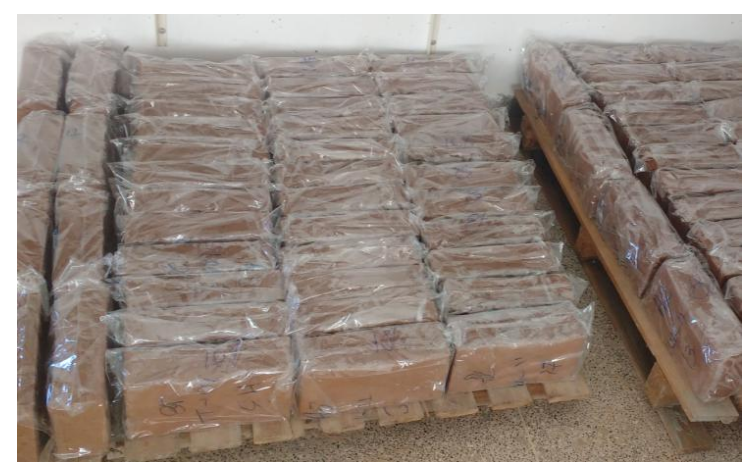

Figure 5. Block cure on humid chamber

\subsubsection{Retraction Analysis}

The retraction analysis of the material was performed by the well-known procedure named box test [30], which consisted on scraping and sieving $3 \mathrm{~kg}$ of soil, which was mixed with cement and fibers [8]. For this test, it is desired to obtain plaster mortar consistence similar appearance of adobe mass. Then, it was adopted the same moisture content during block confection, as the same mixture procedure.

The composite referent to each trace was disposed on one test box compartment, illustrated on Figure 6, which was lubricated with oil and its inner dimension on each compartment: $60 \mathrm{~cm}$ length, $8.5 \mathrm{~cm}$ width and $3.5 \mathrm{~cm}$ height. In sequence, one of the extremities was rose and left to fall under gravity effect at $7 \mathrm{~cm}$ height from the floor, on both extremities.

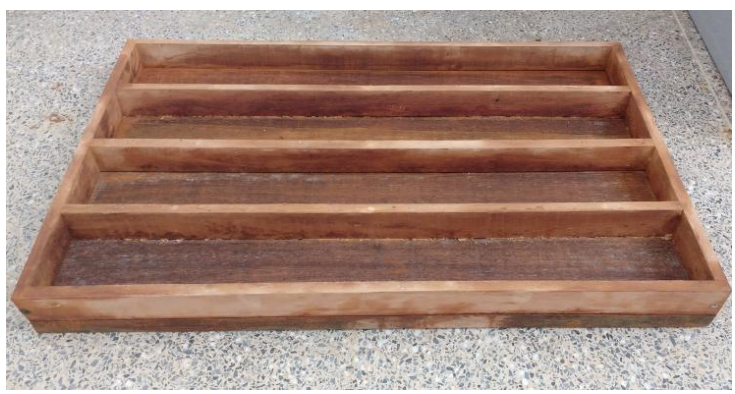

Figure 6. Box for retraction test

After that, the box was conditioned from inclement weather, sun or water exposition for 7 days. The material retraction measurement was made on the major dimension of the box and obtained by the average of 3 measures along the width of the compartment, with precision of $1 \mathrm{~mm}$. For composite retraction behavior be considered satisfactory, the samples should not display cracks and retraction superior to $2 \mathrm{~cm}$.

\subsubsection{Compressive Strength Test (CS)}

Soil-cement blocks compressive strength test is established by ABNT [31], which determines that 10 samples with 7 days cure must be tested. This standard requires the proof tests obtain a minimum compressive strength of $2 \mathrm{MPa}$ for average values and 1.7 MPa for individual values. This test was conducted with the objective to verify the influence of fiber addition on compressive strength in relation to the testimony sample (with no fiber addition).

In this research, the test procedure was adapted, dismissing the immersion stage [32] and the proof test cut before rupture [33]. The covering was executed from mortaring the block superior face, ensuring the parallelism of this face. Two steel plates were used to transfer test load uniformly on the proof test.

\subsubsection{Water Absorption Test (WAT)}

The water absorption test is regulated by ABNT [31], that requires the values of this parameter should not be higher than $20 \%$ for average values and $22 \%$ for individual values on cure at 7 days. The procedure consists on placing 3 proof test on chamber until the mass become consistent and further weighting when the component reaches room temperature. Next, proof test are immersed on water for 24 hours, for then, being withdrawn, dried superficially and weighted again to calculate water absorption by Equation 1 .

$$
A=\left[\frac{\left(m_{2}-m_{1}\right)}{m_{1}}\right] \times 100
$$


Where: $A=$ Water Absorption (\%);

$m_{1}=$ Dry proof test weight;

$m_{2}=$ Proof test weight after immersion.

\subsubsection{Durability Test for Wetting and Drying (DMS)}

DMS test, also known as accelerated aging test, was executed following the regulation disposed by ABNT [34], utilizing the soil-cement blocks as proof test [8] and eliminating the mass loss analysis by brushing process, fact justified to consider the effect of abrasives efforts on masonry components are less severe and more punctual when compared with other soil-cement applications [35].

The analysis was made from determining the durability coefficient, which is obtained on Equation 2. The objective of this parameter is evaluate proof test CS which undergoes DMS test, correlating the average CS value for 7 days curing. The material is considered durable if obtains a durability coefficient equal or higher than $80 \%$ [36].

$$
D=\left(\frac{R C S_{d u r}}{R C S}\right) \times 100
$$

Onde: $D=$ Durability Coefficient (\%);

$R C S_{d u r}=$ CS proof test average value that underwent wetting and drying cycles with 7 days cure.

$R C S=$ CS average values for proof tests broke

The procedure used for proof test rupture on DMS test was the same described on item 2.2.4.

\section{Results and Discussion}

\subsection{Soil Characterization and Classification}

Test results are presented o Table 1.

Table 1. Physical indexes and soil classification

\begin{tabular}{|c|c|}
\hline \multirow{2}{*}{ Granulometry } & Silt + Clay $=33.63 \%$ \\
\cline { 2 - 2 } & Sand $=66.37 \%$ \\
\hline Liquid Limit & $18 \%$ \\
\hline Plasticity Limit & $12 \%$ \\
\hline Plasticity Index & $6 \%$ \\
\hline Apparent Dry Specific Mass & $1.968 \mathrm{~g} / \mathrm{cm}^{3}$ \\
\hline AASHTO Classification & $\mathbf{A - 2 - 4}(\mathbf{0})$ \\
\hline
\end{tabular}

It can be verified the soil utilized is a granular material class A-2-4 (0), being characterized as silty or clay sand with behavior varying from good to excellent as pavement sub base, according AASTHO methodology. From granulometry test, it was checked the sand grains that composes the soil are predominantly fines, with dimensions between 0.42 and $0.075 \mathrm{~mm}$.

\subsection{Adobe Block Traces}

With the soil predominantly sand, the cement proportion was determined based on ABCP table [29], which provides the average cement content for non organic sand soils by the General Standard Soil-Cement Dosage. Therefore, it was obtained a cement content equal to $7 \%$ for soil stabilization, that was used in all traces, as displayed on Table 2 and presents moisture content for each mixture.

Table 2. Traces of analyzed mixtures

\begin{tabular}{|c|c|c|c|c|}
\hline Trace & A1 & A2 & A3 & A4 \\
\hline Kraft Fiber (\%) & 0 & 8 & 10 & 12 \\
\hline Portland Cement (\%) & 7 & 7 & 7 & 7 \\
\hline Moisture Content (\%) & $\mathbf{1 8 , 2}$ & $\mathbf{2 6 , 5}$ & $\mathbf{4 0 , 0}$ & $\mathbf{4 5 , 0}$ \\
\hline
\end{tabular}

Conform it was expected, it is noted the tendency of moisture content increase with the increase of Kraft fiber content, despite this variation do not rise in the same proportion of fiber increment on each mixture. It happens due to empirical and visual determination of water amount.

\subsection{Retraction Analysis}

Retraction test by box method presented satisfactory results for all traces, not being observed crack occurrence on any sample, as represented on Figure 7. It is pointed out the traces with fibers have not displayed significant retraction on measurement, then it can be considered null. For samples without lraft fibers, it was verified an average retraction value equal to $4 \mathrm{~mm}$, lower than the $2 \mathrm{~cm}$ limit disposed on the literature [30].

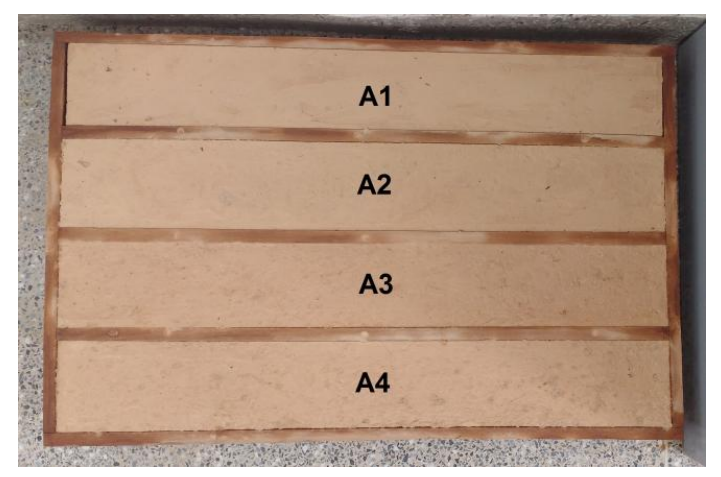

Figure 7. Tested Samples Retraction

\subsection{Compressive Strength}

The results obtained for compressive strength, average and individual values, reached standard values. Average values of compressive strength were $2.56 \mathrm{MPa}$ for testimony sample (without fiber incorporation), 3.12 MPa for 8\% Kraft fiber trace, 3.63 MPa for 10\% Kraft fiber trace and 2.94 MPa for $12 \%$ Kraft fiber trace, as presented on Figure 8.

It is noted that all traces with Kraft fiber addition presented compressive strength higher than testimony sample compressive strength, with differences equal to 0.56 $\mathrm{MPa}, 1.07 \mathrm{MPa}$, and $0.38 \mathrm{MPa}$ for mixtures $\mathrm{A} 2, \mathrm{~A} 3$ and $\mathrm{A} 4$, respectively. This strength gain is attributed to fiber participation that absorbs part of the intern efforts, offering better mechanical properties even after cracks. 


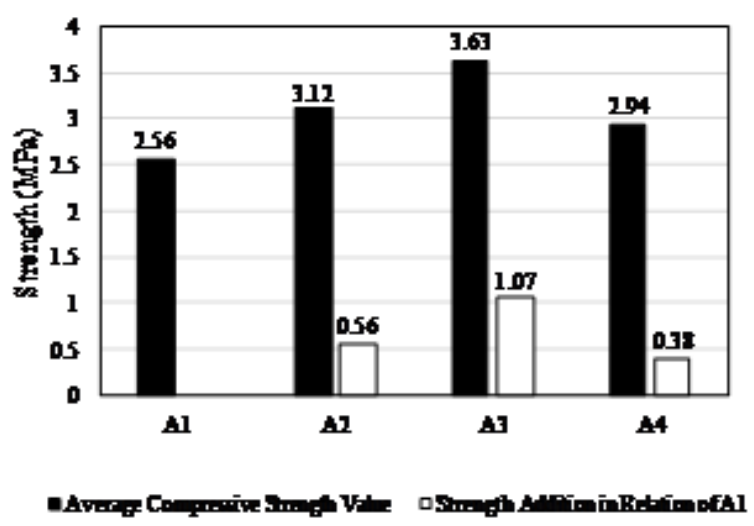

Figure 8. Average CS values and addition in relation to A1 (MPa)

It is important highlight the A3 trace performance obtained the best result among the mixtures analyzed in this search, presenting the best CS, average value of $3.63 \mathrm{MPa}$. This result strength the $10 \%$ Kraft fiber content for sand soils, corroborating with the information disposed on literature [9].

Also, it is notable the decrease on CS on trace A4 in relation to trace $\mathrm{A} 3$, being even lower than trace $\mathrm{A} 2$. This fact is related with water content on the mixture, with a higher water/cement relation for traces A3 and A4 when compared with trace A2. Then, it is demonstrated the possibility to optimize the results adjusting water content.

During the test, it was observed the adobe block crushing phenomenon, fact related with deformation capacity on cracked state and due to Kraft fiber addition. This behavior was more accentuated on traces A2, A3 and A4.

Another factor that influenced the excessive deformation on proof test was the amount of water inside adobe blocks, justified by humid chamber cure whose isolation did not allowed water react with cement during cure period, affecting the composite mechanical strength. The residual water can be seen on Figure 9.

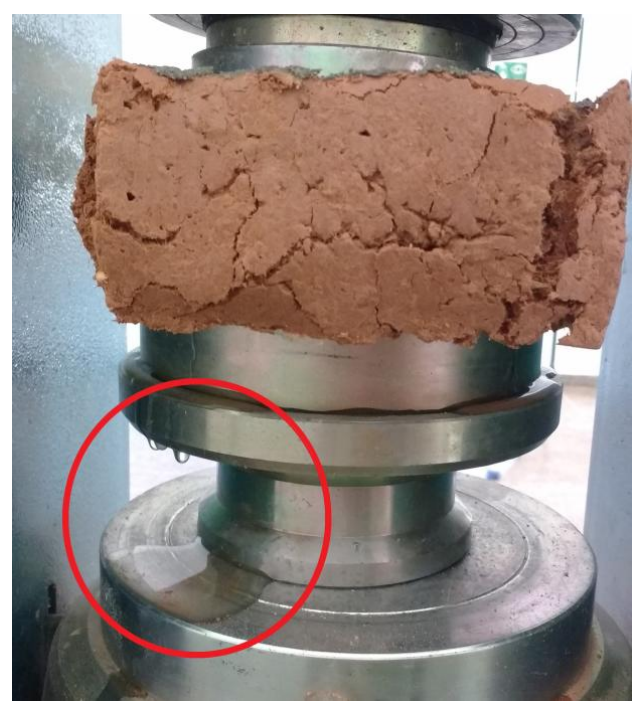

Figure 9. Residual Water observed on CS test

It is noted for Kraft fiber addition traces, blocks did not presented strength peak, with proof test reached the maximum route on machine plate, whose extension is equal to $25 \mathrm{~mm}$, without strength loss. Thus, the obtained values for this samples do not stand for composite compressive strength, but represent the maximum compressive strength on the moment of limit deformation. This situation was not verified on testimony sample, even displaying great deformation, presented strength peaks.

\subsection{Water Absortion (WA)}

In relation of this parameter, only testimony sample presented values under the limit established on standard, which average value required is $20 \%$. The results obtained for each trace are displayed on Figure 10.

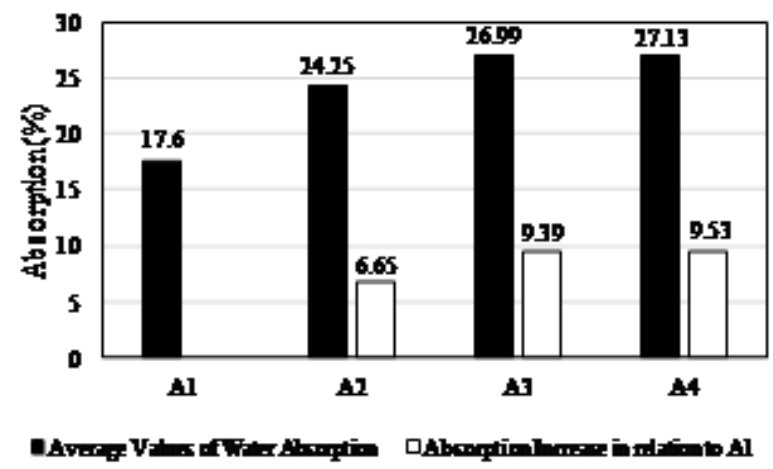

Figure 10. Average Values of WA and increase in relation to A1

It is observed a tendency of WA more accentuated with Kraft fiber content increase, fact also verified on other researches $[8,9]$. However, the elevated absorption index can be justified by the constructive technique. Adobe demands considerable water contents to achieve plasticity, which result on elevated porosity in the material.

This fact justifies the not attendance of normative exigency for Kraft fiber samples, as the not occurrence of proportional absorption increase between traces, due to water increase between traces does not present proportionality on variation.

\subsection{Durability for Wetting and Drying}

Proof test submitted to durability test for wetting and drying did not presented cracks and kept their physical integrity during and after cycles.

The volume variation, humidity and mass loss did not presented a default behavior, being inefficient the data analysis by these parameters, as described on standard. This behavior can be attributed to eventual intern cracking during the cycles of immersion and heating [37]. Then, the analysis was performed based on durability coefficient whose results are presented on Table 3 .

Table 3. Durability Coefficient

\begin{tabular}{|c|c|c|c|c|}
\hline Trace & A1 & A2 & A3 & A4 \\
\hline RCS $_{\text {dur }}(\mathrm{MPa})$ & 5,43 & 7,86 & 8,41 & 7,25 \\
\hline RCS $(\mathrm{MPa})$ & 2,56 & 3,12 & 3,63 & 2,94 \\
\hline D $(\%)$ & $\mathbf{2 1 2 , 1 1}$ & $\mathbf{2 5 1 , 9 2}$ & $\mathbf{2 3 1 , 6 8}$ & $\mathbf{2 3 3 , 3 3}$ \\
\hline
\end{tabular}


It is noted the strength increase for all proof test after accelerated aging test was significant, presenting a durability coefficient superior to $200 \%$ for all traces. The highest increase among mixtures was verified for A2 trace with $251.92 \%$.

These results implies on good resistance for inclement weather and the composite potential to offer better mechanical properties with elevated cure time for soil-cement.

\section{Conclusions}

The performance presented by adobe blocks was satisfactory, offering compressive strength values superior to the required by standard. The mixture whose results stood out on that parameter is the trace with $10 \%$ Kraft fiber, presenting a average strength increase equal to $1.07 \mathrm{MPa}$ in relation to testimony sample, which is equal to a $41.86 \%$ increase. The result obtained strength this kraft fiber content as a reference for sand soils.

During the compressive strength tests, it was checked blocks crashing, which occurred in a accentuated manner on fiber reinforced mixtures and also they did not presented strength peaks, i.e., the obtained data reading correspond to the supported load until the maximum deformation admitted on the machine test. This fact represent the strength increase and energy absorption capacity after material rupture, in other words, composite toughness increase due to kraft fiber addition.

It can be pointed out the significant gain on mechanical strength when submitted to accelerated aging test, which resulted on compressive strength values two times superior to the obtained after 7 days curing. This fact attributes technical quality and durability to the produced composites.

Elevated water absorption indexes were observed with the testimony sample meeting standard demand. This fact is justified by Kraft paper fibers and characteristic porosity due the chosen block confection technique. Adobes demands great plasticity for modeling, elevating composite moisture.

Despite these facts, it is notorious that soil-cement bricks present great potential as construction material, presenting minor environmental impacts and residue production. Also, it becomes more relevant on CCI actual scenario when associated with CCR recycling and other solid residues, as Kraft paper cement bags, representing a possible solution for a sustainable destination for this residue.

A suggestion for further studies the optimization of moisture content for fiber added mixtures, the study of mechanical properties of adobe with different curing time, improvement of water absorption characteristics with other mechanisms of stabilization, the exam of physico-chemical characteristics of percolated water on the brick and the investigation of thermal and acoustic properties of the composite material.

\section{ACKNOWLEDGMENTS}

For all the provided support, the authors thanks the Coordenação de Aperfeiçoamento de Nível Superior (CAPES) and the Conselho Nacional de Desenvolvimento Científico e Tecnológico (CNPq).

\section{REFERENCES}

[1] Lourenço, Patrícia. Arquitectura de Terra: uma visão de futuro. PLANETACAD Estudo - Companhia de Arquitectura e Design, 2002.

[2] Laruccia, M. M. Sustentabilidade e Impactos Ambientais da Construção Civil. Revista ENIAC PESQUISA, vol. 3 nº 1 , 2014.

[3] Ângulo, S. C.; Zorzan, S. E.; John, V. M. Desenvolvimento sustentável e a reciclagem de resíduos na construção civil. In: Seminário Desenvolvimento Sustentável e a Reciclagem na construção civil - materiais reciclados e suas aplicações, CT206 - IBRACON, 4, São Paulo - SP, 2001.

[4] Pinto, T. P.; González, J. L. R. Manejo e Gestão dos Resíduos da Construção Civil. CAIXA ECONÔMICA FEDERAL. Brasília, 2005.

[5] Fernandez, J. A. B. Diagnóstico dos Resíduos Sólidos da Construção Civil. IPEA - Instituto de Pesquisa Econômica Aplicada, Brasília, 2012.

[6] Rocha, J. C.; Cheriaf, Malik. Aproveitamento de Resíduos na Construção. In: Coletânea Habitare, Vol. 4 - Utilização de Resíduos na Construção Habitacional, 2003.

[7] Torgal, F. P.; JALALI, Said. Construção Sustentável. O caso dos Materiais de Construção. In: Congresso Construção 2007 - 3. ${ }^{\circ}$ Congresso Nacional, Coimbra, Portugal, 2007.

[8] Buson, M. A. Kraftterra: Desenvolvimento e Análise Preliminar do Desempenho Técnico de Componentes de Terra com a Incorporação de Fibras de Papel Kraft Provenientes da Reciclagem de Sacos de Cimento para Vedação Vertical. Tese de Doutorado. Universidade de Brasília, Faculdade de Arquitetura e Urbanismo, 2009.

[9] Mogrovejo, D. R. L. Avaliação das Propriedades Geotécnicas de um Solo Argiloso e outro Arenoso com Adição de Fibras de Papel Kraft. Dissertação de mestrado. Universidade Estadual de Campinas, Faculdade de Engenharia Civil, Arquitetura e Urbanismo, 2013.

[10] Alves, L. S. Influência da Adição de Fibras de Celulose (Papel Kraft) nas Características dos Blocos de Concreto Não Estrutural. Dissertação de Mestrado. Universidade de Brasília, Faculdade de Tecnologia, 2016.

[11] Sindicato Nacional da Indútria do Cimento - SNIC (2013): Relatório Annual 2011. Disponível em: <http://snic.org.br/as sets/pdf/relatorio_anual/rel_anual_2013.pdf $>$. Acesso em 06/2018.

[12] Silva, M. A. Obtenção e Caracterização de Compósitos Cimentícios Reforçados com Fibras de Papel de Embalagens de Cimento. Dissertação de Mestrado. CEFET - MG: Centro Federal de Educação Tecnológica de Minas Gerais, 2013. 
[13] Sales, K. C. S. Melhoria de Solos por Inclusão de Fibras Naturais. Dissertação de Mestrado em Geotecnia. Faculdade de Tecnologia, Universidade de Brasília, 2011.

[14] Carvalho, P. E. F; Cintra, Cláudio; Carasek, Helena. Argamassas com Fibras de Celulose Provenientes de Embalagens de Cimento e de Cal. Anais: XIV ENTAC Encontro Nacional de Tecnologia do Ambiente Construído. Juiz de Fora - MG, 2012.

[15] Dutra, M. L..; Kochem, K.; Possan, E. Aproveitamento de Resíduos de Papel Kraft e Gesso na Produção de Argamassas. Anais: $8^{\circ}$ Fórum Internacional de Resíduos Sólidos, Curitiba - PR, 2016.

[16] Martins, D. V. A.; Soares, L. M. Avaliação do Desempenho de Revestimento de Argamassa com Fibras de Papel Kraft Provenientes de Embalagens de Cal. Tese de Conclusão de Curso. Univerdidade Federal de Goiás, Curso de Engenharia Civil, 2016.

[17] Noronha, L. L.; Medeiros, A. F. D.; Barbosa, N. P.; Bezerra, U. T. Gesso e Resíduos de Sacos de Cimento: Propriedades Térmicas de Elementos Construtivos para Forro. In: Materiais de Construção Sustentáveis, vol. 1. Universidade do Minho. março de 2014.

[18] Souza, L. C. C.; Ramos, J. T.; AMARAL, M. E. A.; Neubauer, M. D.; Daltrozo, V. L. Reúso de Sacos de Cimento e de Copos Plásticos Descartáveis na Produção de um Tapume Ecológico de Proteção para Obras de Médio Porte. Mostra Interativa de Produção Estudantil em Educação Científica e Tecnológica, 2017.

[19] Marins, D. S.; Santos, J. H.; Nascimento, B. L. S.; Lima, I. B. G.; Santos, N. M. Resistência à Compressão Simples e Absorção de Água em Tijolos Ecológicos com a Incorporação de Papel Kraft. Anais: $7^{\circ}$ Fórum Internacional de Resíduos Sólidos, Porto Alegre - RS, 2017.

[20] Prompt, Cecília. Curso de Bioconstrução. Ministério do Meio Ambiente. Secretaria de Extrativismo e Desenvolvimento Rural Sustentável. Brasília: MMA, 2008.

[21] Neves, Célia. O Uso do Solo-cimento em Edificações. A Experiência do CEPED. CEPED - Centro de Pesquisas e Desenvolvimento. Rede Ibero-Americana PROTERRA, 2006.

[22] Rotondaro, Rodolfo. ADOBE. In: Técnicas de Construção com Terra. Rede Ibero-Americana PROTERRA. Bauru - SP, 2011.

[23] Morett, H. T. A Importância da inserção dos Sistemas Construtivos de Solocimento no Processo de Industrialização da Construção. Dissertação de Mestrado. Universidade Federal do Rio de Janeiro, Faculdade de Arquitetura e Urbanismo, 2003.
[24] Google Maps. Disponível em: <https://www.google.com/ma $\mathrm{ps} / \mathrm{d} /$ viewer?ll=-15.924438023618132\%2C-52.27586775146 $483 \& \mathrm{spn}=0.075285 \% 2 \mathrm{C} 0.10643 \& \mathrm{hl}=\mathrm{en} \& \mathrm{t}=\mathrm{h} \& \mathrm{msa}=0 \& \mathrm{z}=1$ $5 \& \mathrm{ie}=\mathrm{UTF} 8 \& \mathrm{mid}=1 \mathrm{RS} 4 \mathrm{LDAgUkCV7IYq}-\mathrm{hmKBaO} 2 \mathrm{GHR}$ s>. Acessado em: 20/05/2017.

[25] Associação Brasileira de Normas Técnicas - ABNT: NBR 7181 - Solo - Análise Granulométrica. Rio de Janeiro, 2016.

[26] ABNT. NBR 6459 - Solo - Determinação do Limite de Liquidez. Rio de Janeiro, 2016.

[27] ABNT. NBR 7180 - Solo - Determinação do Limite de Plasticidade. Rio de Janeiro, 2016.

[28] ABNT. NBR 11578 - Cimento Portland Composto. Rio de Janeiro, 1991.

[29] Associação Brasileira de Cimento Portland - ABCP: Dosagem das Misturas de Solo cimento - Normas de Dosagem e Métodos de Ensaio. $3^{\mathrm{a}}$ Edição. São Paulo, 2004.

[30] Centro de Pesquisas e Desenvolvimento. Manual de Construção com solo-cimento - CEPED. Associação Brasileira de Cimento Portland, Programa THABA, 1999

[31] ABNT. NBR 8492 - Tijolo de Solo-cimento - Determinação da Resistência à Compressão e da Absorção D'Água. Rio de Janeiro, 1984.

[32] Pitta, M. R.; Nascimento, A. A. P. Dosagem de Solo Melhorado com Cimento por Modificações Físicas, Químicas e Mecânicas do Solo Original. Estudo Técnico ET-53 da Associação Brasileira de Cimento Portland - ABCP, São Paulo, 1983.

[33] Silva, B. A. Estudo de Misturas Solo-cimento Agregado Reciclado de Telhas Cerâmicas para Fabricação de Blocos para Alvenaria. Dissertação de Mestrado. Universidade Federal de Uberlândia, Minas Gerais, 2015.

[34] ABNT. NBR 13554 - Solo-cimento - Ensaio de Durabilidade por Molhagem e Secagem. Rio de Janeiro, 1996.

[35] Grande, F. M. Fabricação de tijolos modulares de solo-cimento por prensagem manual com e sem adição de sílica ativa. Dissertação de Mestrado. Universidade de São Paulo. Escola de Engenharia de São Carlos, 2003.

[36] Marcon, A. F. Durabilidade e Módulo de Elasticidade de Misturas Areia - Cal - Cinza Volante. Dissertação de Mestrado. Universidade Federal do Rio de Janeiro, 1977.

[37] Ferreira, R. C.; Gobo, J. C. C.; Cunha, A. H. N. Incorporação de Casca de Arroz e de Braquiária e seus Efeitos nas Propriedades Físicas e Mecânicas de Tijolos de Adobe de Solo-cimento. Revista de Engenharia Agrícola, v.28, n.1. Jaboticabal, 2008. 